\title{
Application of Constructivist Teaching Approach in Introducing New Environmental Concepts to Young Elementary Students in the Philippines: A Small Class Sized Experience from Slime Moulds Modeling
}

\author{
Likha Jose Q. Arioder ${ }^{1}$, Veronica Q. Arioder ${ }^{2}$, Violeta V. Quintana², Nikki Heherson Dagamac ${ }^{3}$
}

\author{
${ }^{1}$ Thai Nguyen University of Agriculture and Forestry, Quyết Thắng, Thái Nguyên, VIETNAM \\ ${ }^{2}$ The Learning Place International, PHILIPPINES \\ ${ }^{3}$ University of Greifswald, GERMANY \\ *Corresponding Author: nhadagamac@gmail.com
}

Citation: Arioder, L. J. Q., Arioder, V. Q., Quintana, V. V., \& Dagamac, N. H. (2020). Application of constructivist teaching approach in introducing new environmental concepts to young elementary students in the Philippines: A small class sized experience from slime moulds modeling. Interdisciplinary Journal of Environmental and Science Education, 16(2), e2214. https://doi.org/10.29333/ijese/7818

\section{ARTICLE INFO ABSTRACT}

Received:

11 January 2020

Accepted:

12 February 2020
The traditional elementary science education setting in the Philippines mainly focuses on using macro-organisms as a biological model. To introduce the fundamental environmental concepts of microbial predation and other related environmental concepts such as decomposition, nutrient cycling and species interaction to the young elementary Filipino students, an initial pilot study was conducted in a small classsized setting of one international school in the Philippines. Our goal was to (i) design an activity-based teaching program utilizing the constructivist 5E (engage, explore, explain, elaborate and evaluate) method using solely slime moulds as an example organism and (ii) obtain the impression of the students regarding the activity-based teaching program. A purposive sampling size with a total of 45 number of students aging from 10-12 years old were divided into control (16) and experimental (29) groups. Likert scale survey was also given to the student experimental group to assess their overall impression about the newly developed teaching program. Significant differences on test scores between the control and experimental group and the high priority mean scores given by the experimental group points out the effective facilitation of the program. Hence, innovations in teaching pedagogies for difficult science concepts such as the development of the Slimy Business teaching program improves not only the learning quality of the young learners but as well as their environmental appreciation. Applying such novel teaching approach in the conservative Philippine elementary schools is recommended.

Keywords: active learning, elementary education, Myxomycetes, stem, science teaching strategy

\section{INTRODUCTION}

Today, the interdisciplinary teaching approach is a key concept to the advancement of school curriculum at all levels. Currently, debates are still ongoing on whether it is the best approach for elementary school curriculum. The approach has advantages such as stimulating student's appreciation of the different disciplines and enriching communication skills especially among the young generation (Jones, 2010). The present young generation now branded as Generation- $Z$ can be the most effective disseminators of the beneficial uses of environmentally important organisms. Children are more pliant and open-minded since they are devoid of prejudices and biases and can easily absorb new ideas (Bowles, 2005). To be effective disseminators, the creative skills of these children, who are more imaginative, showing inventiveness and originality of thought, should be initially developed by exposing them to different learning environments (Longshaw, 2009).

Longshaw (2009) advocated that more educational strategies must be developed through creative lessons that encourage students to 'think outside the box' and come up with off the wall ideas. In an earlier report of Dale and Newman, (2005) they discussed that merging sustainability and development requires a complex interdisciplinary approach beyond what can be found 
in some areas of traditional way of educating students about the environment. Interdisciplinary approach in science education systems in many parts of the world is the theme called "environmental education". According to UNESCO (2008), Environmental education (EE) is a lifelong process with the objective of imparting to its target groups in the formal and non-formal education sectors environmental awareness, ecological knowledge, attitudes, values, commitments for actions, and ethical responsibilities for the rational use of resources and for sound and sustainable development. Moreover, it is in the early childhood period that children develop their basic values, skills, attitudes and behaviours which may be long lasting. Indeed, helping young learners understand the importance of any organism and their roles they portrays in the environment is a big initial step in building an environmentally aware young ecowarriors. However, these methods in environmental education require children first to be familiarized with foundational concepts i.e. the unique world of many underappreciated but highly significant environmental model organisms. Thus, developing educational programs and/or laboratory protocols that aid in understanding the complexities of environmentally important biological organisms for learners is essential. In particular, the neglected organisms are the myxomycetes or the so called plasmodial slime moulds.

Slime moulds (Myxomycetes) are enigmatic eukaryotic microorganisms (Schnittler et al., 2017) with very intricate and complicated fructifications as compared to the common fungi such as mushrooms and yeasts (Stephenson, 2011; Dagamac et al., 2017). Unlike other microbes, slime moulds provide an opportunity to work with live specimens without posting any risk factors to students or teachers since they are non-pathogenic, non-toxic and hypoallergenic (Winsett et al., 2017). Slime moulds are also one of the well documented biological organisms in Western biological textbooks because of its complex life cycle that makes them ideal organisms to explain cell to cell interactions (Keller \& Everhart, 2010).Their complex life cycle involves shifting from a brainless blob predator to fungus-like fructification (Keller et al., 2008). Similarly, besides being used as models for local conservation (Almadrones-Reyes \& Dagamac, 2018), they also serves as beneficial components of the soil ecosystems (Dagamac et al. 2011). The peculiarity of slime molds as predators of many microorganisms thus limit their population density (Schnittler et al., 2012). The environmental roles of movement and ingestion without any nervous system make slime moulds the flagship model of primitive intelligence (Nakagaki et al., 2000; Beekman \& Latty, 2015). In fact, controlled laboratory experiments prove their ability to navigate over complex mazes through external spatial memory system (Nakagaki, 2001; Reid et al., 2012).

Furthermore, slime moulds are easily recognizable in terrestrial ecosystems with suitable habitat conditions (Novozhilov et al., 2018). This is well-appreciated by students doing outdoor field excursions. If not found in the field, they may serve as an alternative laboratory component which is an effective teaching strategy (Winsett et al., 2017) since slime moulds can be cultured easily using the practical moist chamber technique (Bernardo et al., 2018; Dagamac et al. 2015). These attributes prompt scientists, enthusiast and non-experts fascinated with slime moulds. In spite of the beneficial uses and the significant environmental roles of slime moulds as a model organism for science teaching, unfortunately, Filipino students are still unexposed to them (Macabago \& dela Cruz, 2012).

Interestingly, schools in the country concentrated only on topics like common plants and animals, ignoring a very valuable component of natural biodiversity, which are the terrestrial protists, particularly the slime moulds. Therefore, using them as a model organism to impart an environmental concept such as predation and nutrient cycling to Filipino elementary students is indeed a promising feat. Hence, necessity for a constructive teaching approach in introducing new environmental concepts to young Filipino elementary students using slime mould models.

\section{MATERIALS \& METHOD}

For the purpose of this study, this section was divided into two (2) subdivisions: content and creative teaching program development based on 5Es model, and evaluating students' impression. To introduce the fundamental environmental concepts of microbial predation and other related environmental concepts such as decomposition, nutrient cycling and species interaction to the young elementary Filipino students, this pilot study was conducted at The Learning Place International in Los Baños, Laguna a progressive school in the Philippines that uses LifePACS curriculum by AlphaOmega Publications. The LifePACS/ learning modules are progressively designed to develop student's critical and analytical thinking skills which are why the school allowed the researchers to subject its students to the creative teaching program. A purposive sampling size with a total of 45 number of students aging from 10-12 years old were used for this study; the students were randomly grouped into control (16) and experimental (29). Initially, both groups were subsequently given a pre-test examination that would be covered in the program. With the exception of the control group, the experimental group was then subjected to the program for a span of two weeks. The programs were given to them gradually with around 60 minutes of the time given 
for every session. Afterwards, a post-test evaluation was given to both groups. To test the null hypothesis that the test scores for both study groups (control and experimental) has no significant difference, a parametric t-test was evaluated between test scores of each group.

The goal was to design an activity-based teaching program utilizing the constructivist 5Es (engage, explore, explain, elaborate and evaluate) method with slime moulds as an example organism. The study further focuses on obtaining the impression of the students that participated in the activity-based teaching program.

\section{Content and Creative Teaching Program Development Based on 5E Model}

Several literatures regarding slime moulds were used to create the teaching program. Initially, the major concepts that the young learners should learn were identified. Then, from these concepts, various engaging and interactive activities were designed to be included in the teaching program. Afterwards, the final design of the teaching program was validated with regards to its contents by myxomycete experts in the University of Greifswald and all the elementary science teachers of The Learning Place international before it was presented to the students of the school. All of the 10 elementary science teachers answered a 15-items survey to get their impression about the teaching program. They rated the teaching program based on four categories namely appeal as a teaching strategy, format, instructions, and materials. For this study, a two weeks long teaching program entitled "The Slimy Business" was newly developed wherein students were expected to synthesize their new understanding from some prior knowledge and new information. Hence, the $5 \mathrm{E}$ constructivist model was adapted for the construction of the teaching program. The motivation to use the model was because this approach claims for students' redefinition and reorganization of their initial concepts through interaction with their environment (Duran \& Duran, 2004). In fact, over the past decades, this model has been used by other studies to explain other science concepts like buoyancy (Cepni \& Sahin, 2012) and circulatory system (Cardak et al., 2008) among elementary students. These reports have subjected students into several teaching methods that proved many students may have more than one learning style (Riener \& Willingham, 2010) which lead into difficulties in learning new knowledge in the classroom. As a result, science teachers continuously strive to improve the methods in which they instruct to enhance student learning (Ramsden \& Moses, 1992).

Each of the 5Es are divided into different learning and teaching phases. The first phase (engagement phase) involves connection of lessons the learners have previously learned in the past and their present learning experience. The phase helps learners to mentally and actively engage in the new concepts that will be introduced to them since there is connection between the past and present knowledge. In this phase, a story reading activity using a comic book with fictional myxomycete characters was conducted. An interactive card-picking game was designed so that the young learners could review some previous and current knowledge about microorganisms. At the exploration phase of the program, two parallel activities were introduced. Firstly, a nature trail activity was performed by the students wherein they were able to go outside the classroom and explore a real forest environment where slime moulds are abundantly occurring when the conditions are favourable i.e. having more moisture but less sunlight. Secondly, a hands-on activity made the students view real slime moulds using simple light microscopes. Live specimens of slime moulds were obtained by one of the authors and stored in herbarium boxes for further use. However, during the explanation phase of the program, students were given opportunities to verbalize their understanding and to demonstrate the acquired skills and behaviours. This phase provided the teachers opportunities to introduce formal terms, definitions, and explanations for concepts, processes, skills and behaviours. During this phase, a short animation entitled "Myxo Maestro" customized by one of the authors about slime moulds' life cycle and environmental significance of slime moulds was viewed by the students. The process helped the students to learn the concepts of decomposition, nutrient cycling and microbial predation of the organism. Contents such as the life cycle and their role in nature were included in this visual animation. Thereafter, an interactive discussion about the animation was entertained by the facilitators to determine how much the students had learned from the animation. In the fourth phase (elaborate phase), the young learners were encouraged to use different art activities such as puppetry, role playing/comic-making, dancing, and singing to showcase not only their creativity but also to intensify their environmental appreciation using slime moulds as their biological model. Lastly, in the evaluation phase, - two responses were elicited from the young learners. The first type of response was the typical written examination with 20 -items multiple choices test. The test questions were then subjected to analysis to measure the level of difficulty of each question. For the second type of response a Likert scale questions that measured the students' satisfaction and impression about the activity-based teaching program was accomplished. 

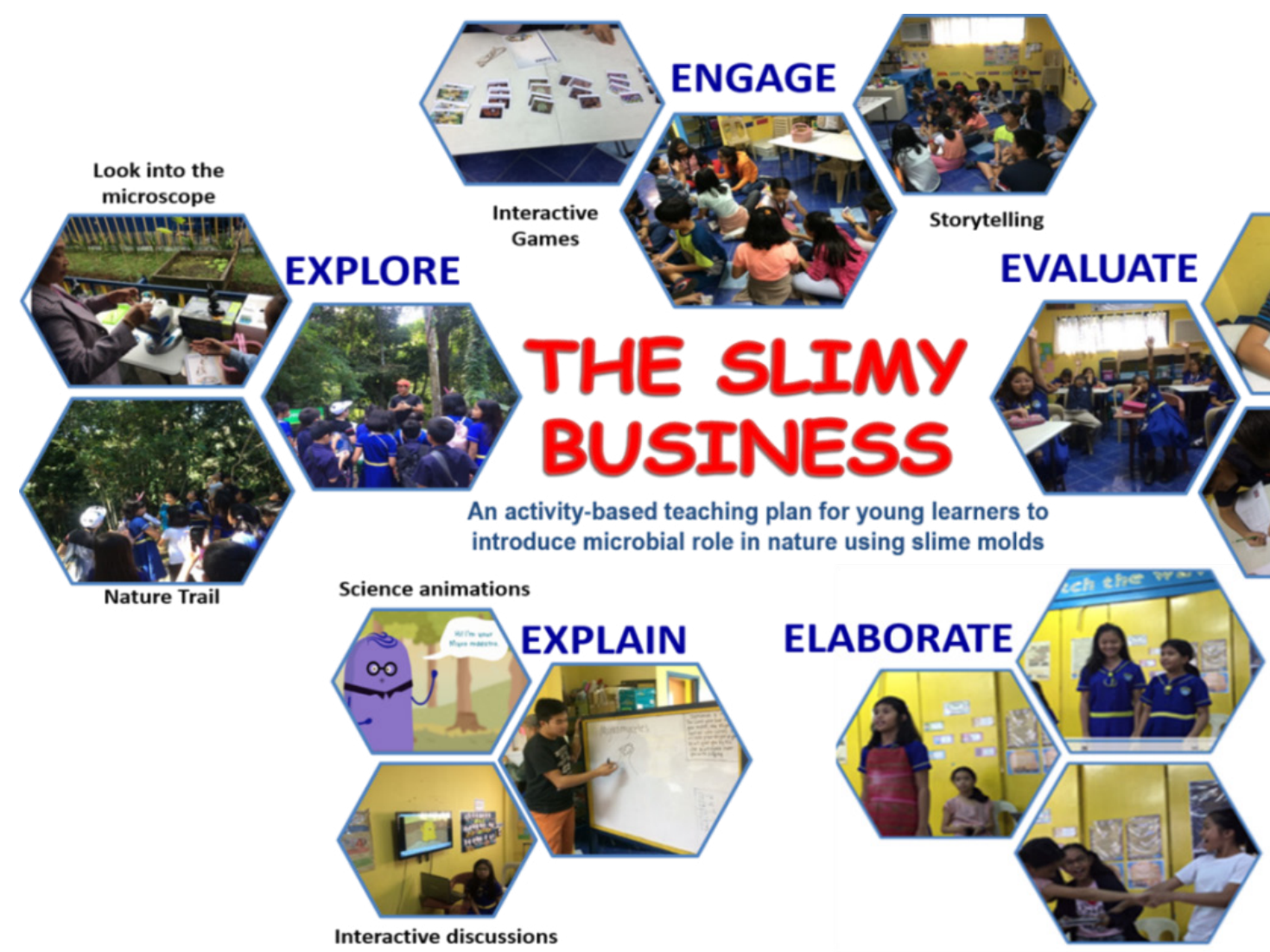

Figure 1. The creative teaching program that was develop to introduce slime moulds using the $5 \mathrm{E}$ constructivist model

\section{Evaluating Students' Impression}

To be able to measure the impressions of the student respondents, the Likert-scale type of tests were used in this study which is patterned from the works of Evangelista et al. (2015) that also used the Likert tests to evaluate the bio-kit manual guide. The report emphasized the importance of knowing how the children thought of their facilitators and how this can determine the success of the entire program (Rogoff, 1994). This was influenced by several other studies and sources of information that encourage the students to have positive attitudes all throughout the program so as to better comprehend and have deeper understanding of the subject matter (Kals et al., 1999). In terms of students' impression about the teaching program, only the experimental group (students) was given additional questionnaire during the Evaluation phase of the program. A 20-item survey was developed to seek the subjective and relative impressions of the experimental group about the program. The acceptability level was measured using a 5-point system gauging the degree of agreement of the young student respondents on the three categories presented in the questionnaire. The three categories that were used in the survey were divided into (i) student's impression about the facilitator who conducted the program which included the facilitator's skills to give clear instructions, engagement, creativity, to be enthusiasm in discussing new concepts, friendliness and approachability to the students, helpfulness to student's inquiries, organization in classroom management and mastery in planning and subjecting the activities, (ii) the level of difficulty of the evaluation test that was given to them and (iii) their overall impression about the activity-based program subject that included the program's comprehensibility, effectiveness, environmental appreciation, entertainment value, practicality, suitability to learn new environmental concepts, and their overall satisfaction about the whole program. The Likert scores given by each student respondents were then tabulated in an MS Excel 2010. The spread sheets scores were then translated into an input file that was subjected in the software Tableau Public v. 10.5 to visualize all the Likert responses in the surveys. The agreement and disagreement level for each category was measured based on the calculated mean scores. Mean scores from $1.00-3.00$ is considered low priority (disagreed by the respondents) while those from $3.01-5.00$ is considered high priority (agreed by the respondents).

\section{RESULTS}

A creative teaching program entitled The Slimy Business (Figure 1) was develop and was subjected to small class sized progressive school of The Learning Place 


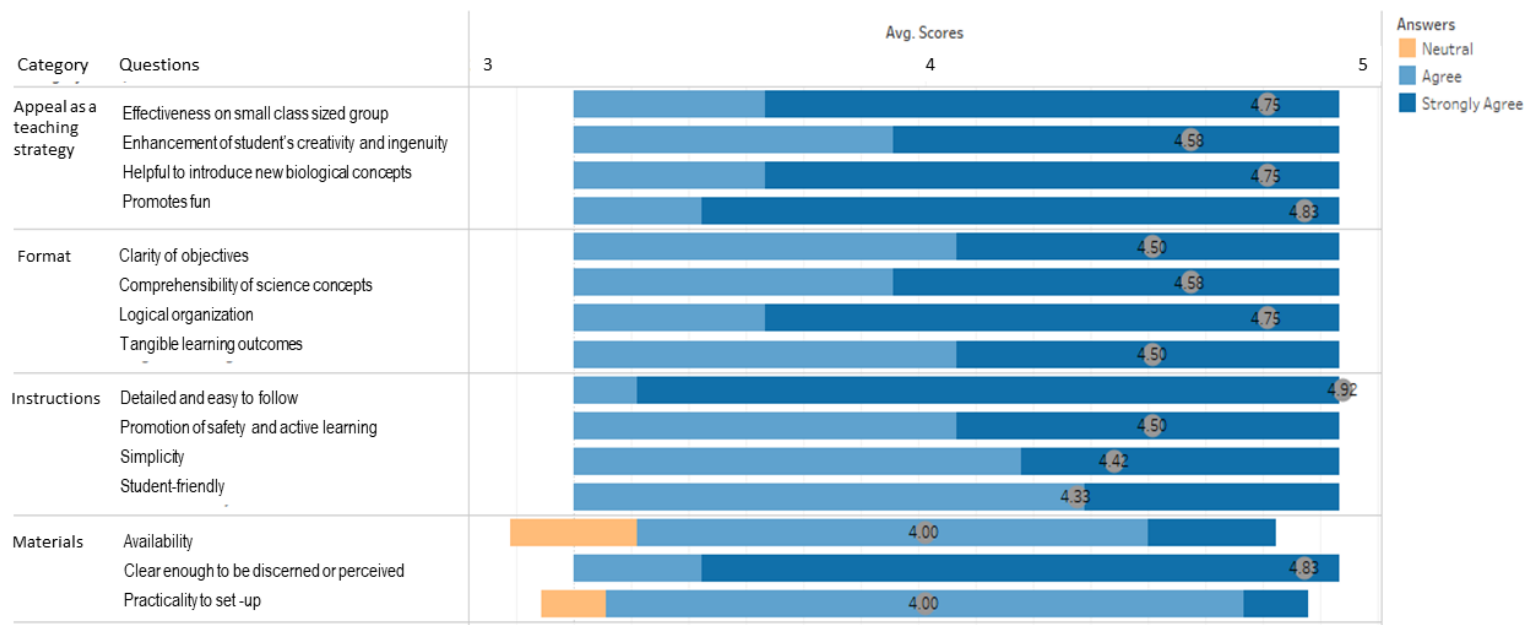

Figure 2. Teacher's perception displayed from the Likert scale responses of selected teachers from The Learning Place International. The grey circles display the average score per category
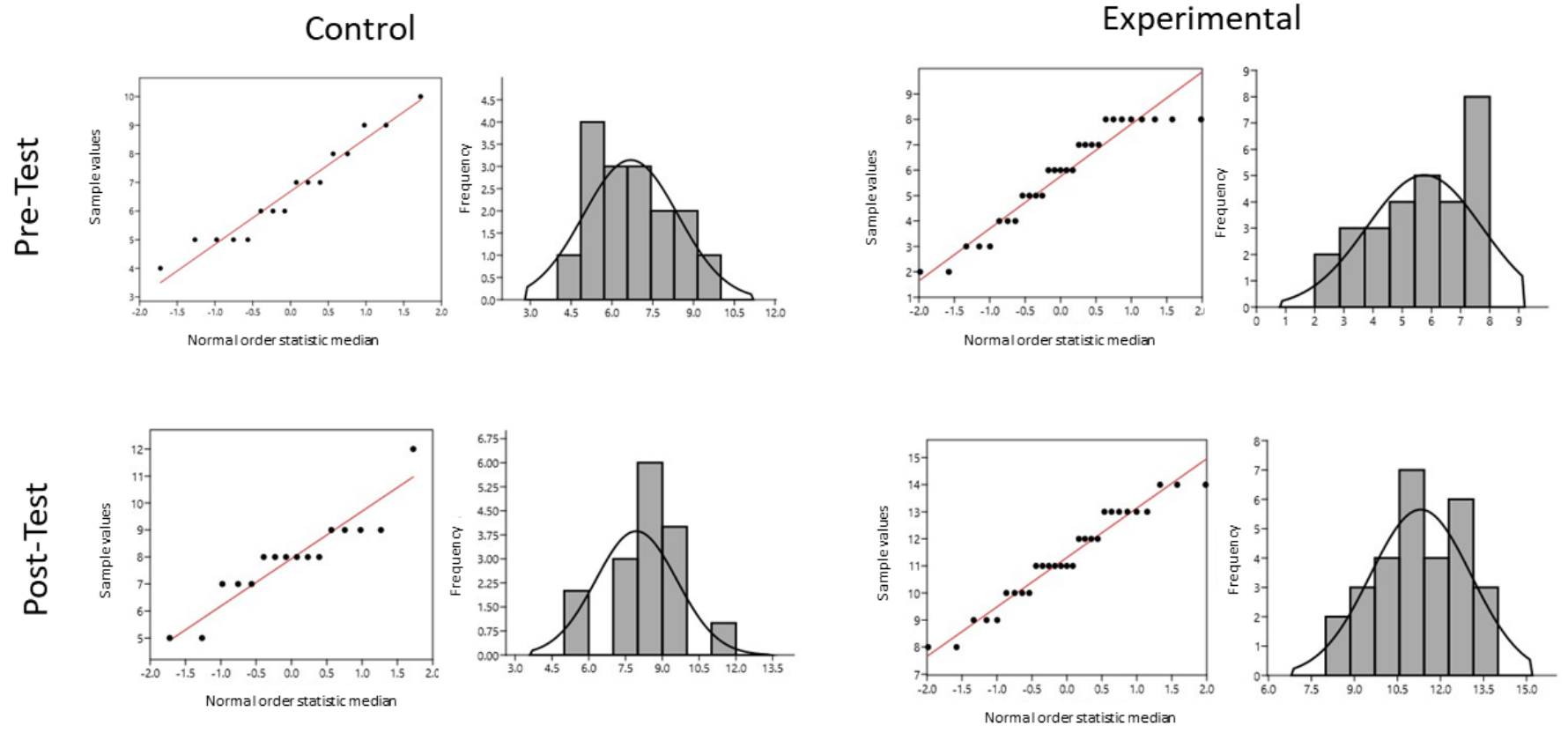

Figure 3. Normality plots and histograms of Pre- and Post- Tests of both Control and Experimental groups

International in Los Baños, Laguna to understand the environmental concepts of nutrient cycling, predation and decomposition using slime moulds as the model organism. In terms of the perception of the science teachers from the Learning Place about the program itself, the results showed (Figure 2) that they were all in strong agreement with its appeal as a teaching strategy with a score ranging from $4.58-4.83$. With regards to the instruction manual provided in the teaching program, the teachers were in strong agreement with its clarity, comprehensibility and organization with a score ranging from $4.50-4.75$. The descriptive statistical analysis in this study shows that the pre- and post-test scores of the control and experimental group followed a goodness of fit model and a bell shaped curve histogram plots (Figure 3).

Moreover, to further test the normality of the test scores, the Shapiro-Wilk Test was calculated and the results were: Experimental $=(0.90)$ and $(0.94)$ for the preand post-test, respectively. The control group $=(0.95)$ and $(0.89)$ for the pre- and post-test, respectively. With these results, the pre- and post-test results for both of the student groups passed the normality tests and are inferred 


\section{Control}
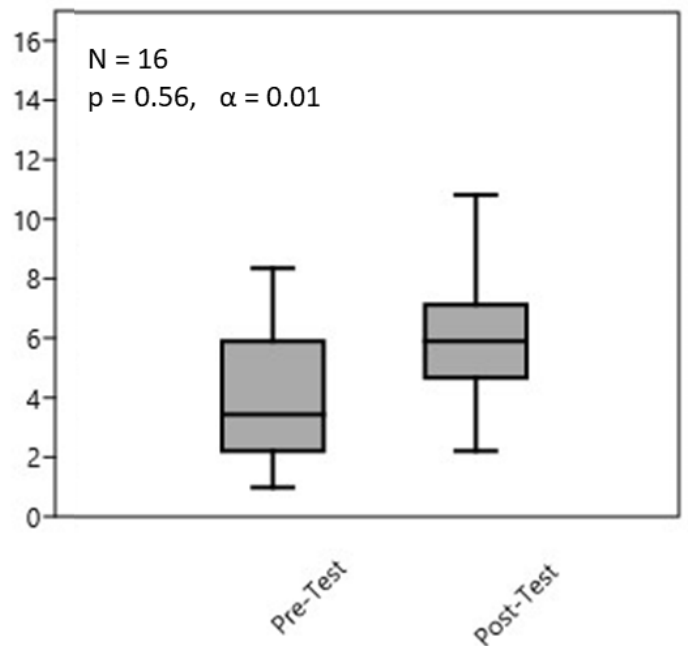

Experimental

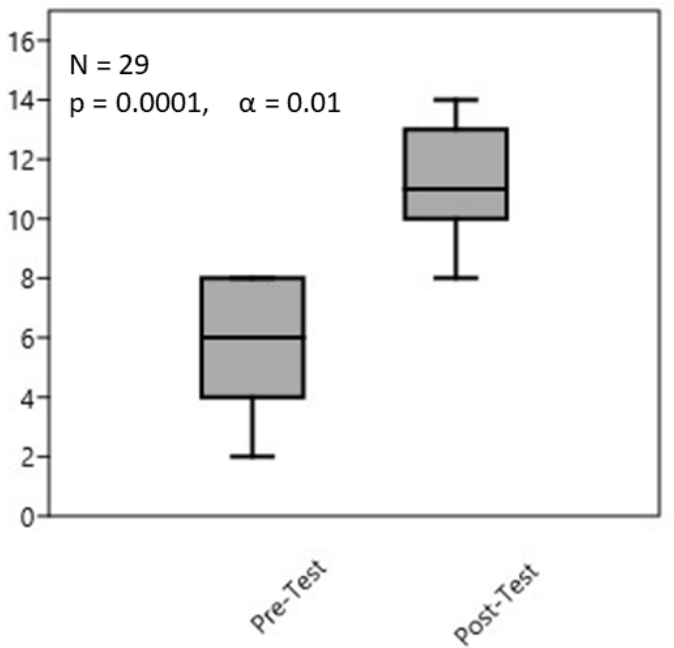

Figure 4. Box plots of Pre- and Post - Tests of both Control and Experimental groups

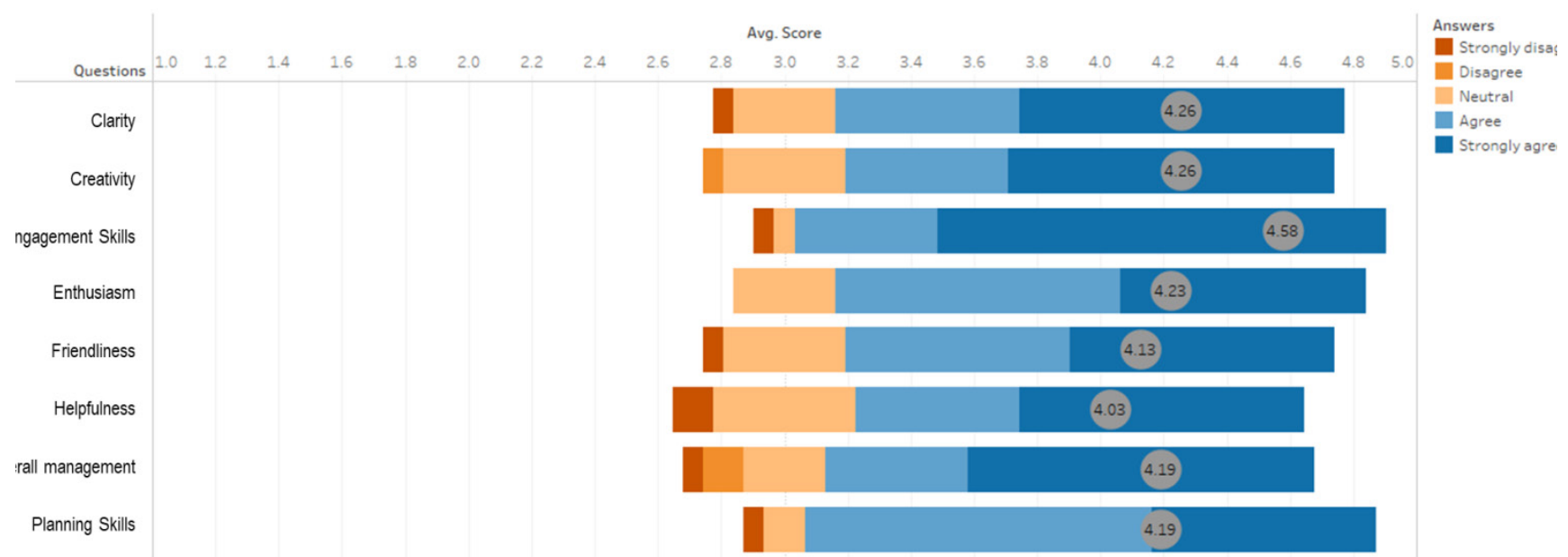

Figure 5. Student's perception about the facilitators. The grey cilesin the graph indicate the average score of the students per question

as normally distributed data. Hence, no data transformation was necessary and for further inferential statistical analysis, parametric tests were used. The results (Figure 4) shows that, there was no significant difference between the pre- and post-test scores of the control group because $p>.01$ (i.e. $p=.56, a=.01$ ). On the other hand, a clear significant difference $(p<.01)$ existed between the pre- and post-test scores of the experimental group (refer Figure 4).

Results on students' (experimental groups) impression about the facilitator of the program are shown in Figure 5. Through the Slimy Business activity-based teaching program the students' (experimental group) impression shows a clear strong liking among the participants (Figure 5). The mean scores of the Likert responses range from 3.87 - 4.39. From the figure (Figure 5), students agreed that they are satisfied with how the facilitator presented the program to them (mean score $=4.39$ ). They also find a high agreement that the facilitator was not only effective (mean score $=4.32$ ) but also has a very fun and entertaining (mean score $=4.32$ ) way of delivering the concepts to them. Through the teaching tool used by the facilitator, the students also agreed that learning about the new concepts made them appreciate the environment even more (mean score $=4.23$ ). Furthermore, in terms of the students' perception about the facilitator of the program, the result shows that the respondents were satisfied with the way they were facilitated. The mean scores obtained as regards this ranged from $4.03-4.58$. Similarly, results on clarity of the activities shows mean score of 4.26 . This translates agreement among the students' respondents that the activities' instructions were clear and understood. Students were very satisfied (mean scores $=4.58$ ) with the engagement skills of the facilitator. In addition, the students acquiesce that the entire program (mean 
score $=4.26$ ) was creative. On overall management and planning of the program, it was concurred (mean scores $=4.19$ ) among the students that the facilitator had good skill.

\section{DISCUSSION}

\section{Development of an Activity Based Teaching Program} Based on 5E Instructional Method

The high satisfaction and approval $(4.58-4.83)$ about the appeal of the program to children, the clarity of the instruction manual and the availability of the required materials of the elementary science teachers (Figure 6) affirmed not only the new concepts that will be introduced to the young learners but also the validation of the method and how it will be delivered to the students. Consequently, it was safe to assume that the adaptation of the $5 \mathrm{E}$ constructivist method to the teaching program engaged the variety of young Filipino students and potentially gave them new knowledge about the unpopular biological organisms like the slime moulds. Moreover, similar studies have shown that teachers like using the $5 \mathrm{E}$ methods in science (Fazelian \& Soraghi, 2010; Ergin, 2012) and even in a math classroom (Tural et al., 2010; Tuna \& Kacar, 2013). Hence, the constructivist nature of this innovative teaching program agrees to the educational principle that the sustained use of an effective, research-based instructional model can help students learn fundamental concepts in science and other domains (Halpern, 1998). As evident in the box plots (Figure 4), there is significance difference in the evaluation test scores of experimental groups (students who participated in the teaching program) while among the control groups there is no significance different. These differences identified amongst the experimental groups can be attributed to different possible factors. The factors can be partly due to the use of a visual aid in the form of comic book reading and a personally developed animation about myxomycetes' role on the environment was involved in both the engage and explains phases. This is in accordance with the findings of Barrett et al. (2015) that proved that there is a $16 \%$ impact on the rate pupils learn because they are more focused when the lessons are taught in a visual or creative manner. Our result seems to be supported by several other studies that have used the same approach in teaching complex biology concepts where students significantly perform better in their examinations after being taught using visual aids (Mayer \& Moreno, 2002; Klees \& Piepenbring, 2018).

Secondly, activities conducted in the explore phase, such as the nature trail study wherein students had the opportunity to know where slime moulds are located in the environment and the microscope activity that allowed them to see different species of myxomycetes in all its life stages were pointed out by earlier similar studies like the one by Vaske and Kobrin (2001) that used nature trail studies and various related activities outside the classroom. In agreement with the studies by Uitto et al., (2006) and Boyes and Stanisstreet (2012), the exposure of the experimental group in the outside classroom activity may have encourage students' learning about their surrounding environment. Another factor that influenced the success of the program was the fourth phase's Elaborate that extended the students' conceptual understanding and allowed them to practice skills and behaviors. The students had the freedom to choose from puppetry, role playing, comic making, singing or dancing to showcase not only their creativity but also to guarantee their environmental appreciation. Evidently, the mean score (4.36) of the students impression on the program being fun and entertaining (see Figure 6) showed that the students were encouraged to express their creativity through performing

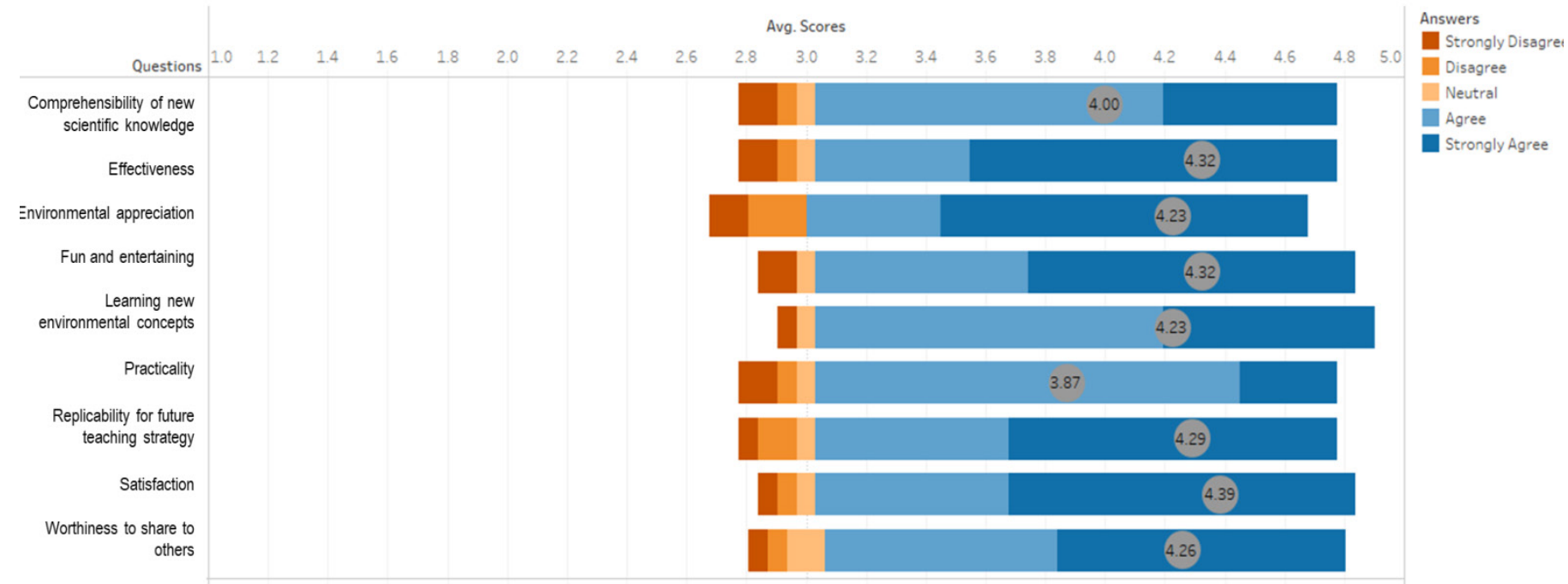

Figure 6. Student perceptions about the whole creative teaching program. The grey circles in the graph indicate the average score obtained per topic 
their individual presentations or artworks. This claim is supported by other related studies (see Csikszentmihalyi, 1996; Amabile, 1996; Auh, 1997) that developed teaching strategies that enhance student's creativity. Similar to the findings of Humston and Ortiz-Barney (2007) and Alexander and Poyyamoli (2014), the teaching program developed and subjected to the students in this study enhanced the students' prior knowledge about slime moulds and its role in the ecosystem.

\section{Impression of the Teaching Program}

With a mean score of 4.32 , the children agreed their facilitators were effective and have indeed given them a fun learning experience (refer Figure 5). Consequently, the engaging material will give the students a good overall impression about the material itself. Moreover, the Likert responses ranging from $3.87-4.39$, regarding the overall impression of the children towards the entire activity based teaching program showed a clear fondness and could perhaps be the main reason for the success of the Slimy Business program shown in Figure 6.

Moreover, the experimental group of students is in strong agreement that learning about the new concepts from the creative teaching program made them appreciate the environment even more (see Figure 6). There are several teaching tools that help children to appreciate lesson taught in or outside the class corridor. One of these tools is visual aids which are vital tool for teaching children some concepts (Cuban, 1986). Dalacosta et al. (2009) as well as Klees and Piepenbring (2018) were of the view that children are more inclined, can easily relate and appreciate animations they watch or sees by themselves as the characters in a film or taught through practical than those taught abstractly. Therefore, the animation developed by the researcher in this study for example, provided a story line personifying slime moulds, providing admirable characters and showing what they do in the forest as if they were actual human beings.

Like a study conducted by Samuelsson and Kaga (2008), students used in the current study were more proactive and inclined to shaping their communities because as early as possible they were able to feel and valued their environment.

\section{CONCLUSION}

Studies have found that the methods and styles that teachers have used in the previous generations can no longer be applied to this present generation because learning styles are continuously evolving. This is because of the alarming fact that the new generations of students are less engaged in the traditional teaching styles of present day STEM teachers. Students become bored and inattentive in class, do poorly on tests, and get discouraged about the courses and the curriculum (Felder \& Silverman, 1988). Our teaching program is unique in a way that it integrates creativity, critical thinking, and environmental appreciation in a holistic manner for young elementary students and at the same time introduces important biological concepts using an unpopular model organism which eventually heightens the curiosity of the children on the diversity of life forms in the planet. Moreover, it is very interesting to highlight that innovations in teaching pedagogies improves the learning quality not only by the young learners but as well as different types of students.

\section{LIMITATIONS OF THE STUDY}

The main challenge of utilizing slime moulds as a biological model was looking for similar researches that have used the organism in their teaching tool for young elementary learners. This study being the first of its kind, found it challenging to make a program that could guarantee children the ability to comprehend such complex microorganism let alone animate it and make it look appealing. Moreover, the conservative nature of most elementary schools in the Philippines that are strictly conformed to structured blackboard teaching instruction makes it difficult to convince them to deviate from their traditional teaching strategies and try an alternative method of discussing new environmental concepts in their schools.

\section{RECOMMENDATIONS}

Teachers should be more engaging and should become more creative in introducing concepts in their lessons to facilitate effective classroom learning. Although plants or animals as biological models have been the trend for many decades in the Philippines, this study presents slime moulds as an alternative model that would be used as an example to explain important scientific concepts like species interactions (predation), nutrient cycling and decomposition. These biological concepts are important environmental ideas that when introduced to young Filipino students early on may enhance their understanding about nature conservation and sustainability. The results of this pilot study suggest that the teaching strategy that was developed creates positive impression to young learners. Hence, employing the constructivism teaching approach that employs fascinating biological model is recommended to be incorporated in other progressive schools' science curricula in other provinces of the Philippines. 


\section{ACKNOWLEDGEMENTS}

LJQA and NHAD would like to acknowledge the SusEnMan (Sustainable Environmental Management) Project (DAAD Project 57218030) headed by Prof. Dr. W. Steingrube for the grant given for a 3-month research internship. The authors would like to acknowledge Paola Cerda and Dr. Duong Van Thao for the technical assistance for this study. Moreover, the authors are indebted to the two anonymous reviewers that gave constructive criticisms that helped in the improvement of this paper.

\section{REFERENCES}

Alexandar, R., \& Poyyamoli, G. (2014). The effectiveness of environmental education for sustainable development based on active teaching and learning at high school level-a case study from Puducherry and Cuddalore regions, India. Journal of Sustainability Education, 7, (http://www.susted.org).

Almadrones-Reyes, K.J., \& Dagamac, N.H.A. (2018). Predicting local habitat suitability in changing climate scenarios: Applying species distribution modelling for Diderma hemisphaericum. Current Research in Environmental and Applied Mycology, 8(5), 492-500. doi 10.5943/cream/8/5/2.

Amabile, T.M. (1996). Creativity in context: Update to the social psychology of creativity. Hachette UK.

Auh, M.S. (1997) Prediction of musical creativity in composition among selected variables for upper elementary students. Bulletin of the Council for Research in Music Education, 2, 1-8.

Barrett, P., Davies, F., Zhang, Y., \& Barrett, L. (2015). The impact of classroom design on pupils' learning: Final results of a holistic, multi-level analysis. Building and Environment, 89,118-133. https://doi.org/10.1016/j.buildenv.2015.02.013.

Beekman, M., \& Latty, T. (2015). Brainless but multi-headed: decision making by the acellular slime mould Physarum polycephalum. Journal of Molecular Biology, 427(23), 37343743. https://doi.org/10.1016/j.jmb.2015.07.007.

Bernardo, J.L.M, Arioder, L.J.Q., Almadrones-Reyes, K.J., \& Dagamac, N.H.A. (2018). Myxomycete communities occurring on fragmented forest patches in two municipalities of Laguna, Philippines. Community Ecology, 19(3), 289-299. https://doi.org/10.1556/168.2018.19.3.10.

Bowles, R. (2005). Children's voices: Younger children versus pedagogy. International Research in Geographical and Environmental Education, 14(4), 295-296. https://doi. org/10.1080/10382040508668361.

Boyes, E., \& Stanisstreet, M. (2012). Environmental education for behaviour change: Which actions should be targeted? International Journal of Science Education, 34(10),1591-1614. https://doi.org/10.1080/09500693.2011.584079

Cardak, O., Dikmenli, M., \& Saritas, O. (2008). Effect of 5E instructional model in student success in primary school 6th year circulatory system topic. Asia-Pacific Forum on Science Learning and Teaching, 9(2), 1-11.

Csikszentmihalyi, M. (1996). Creativity! Flow and the psychology of discovery and invention. New York: Harper Collins.

Çepni, S., \& Şahin, C. (2012). Effect of different teaching methods and techniques embedded in the $5 \mathrm{E}$ instructional model on students' learning about buoyancy force. Eurasian
Journal of Physics and Chemistry Education, 4(2), 97-127.

Cuban, L. (1986). Teachers and machines: The classroom use of technology since 1920. Teachers College Press.

Dagamac, N.H.A., dela Cruz, T.E.E., Pangilinan, M.V.B., \& Stephenson, S.L. (2011). List of species collected and interactive database of myxomycetes (plasmodial slime molds) for Mt. Arayat National Park, Pampanga, Philippines. Mycosphere, 2, 449-455.

Dagamac, N.H.A, Rea-Maminta, M.A.D., \& dela Cruz, T.E.E. (2015). Plasmodial slime molds of a tropical karst forest, Quezon national Park, the Philippines. Pacific Science, 69,407-418. https://doi.org/10.2984/69.3.9.

Dagamac, N.H.A., Novozhilov, Y.K., Stephenson, S.L., Lado, C., Rojas, C., dela Cruz, T.E.E., Unterseher, M., \& Schnittler, M. (2017). Biogeographical assessment of myxomycetes assemblages from Neotropical and Asian Paleotropical forests. Journal of Biogeography, 44, 1524-1536. https://doi. org/10.1111/jbi.12985.

Dalacosta, K., Kamariotaki-Paparrigopoulou, M., Palyvos, J.A., \& Spyrellis, N. (2009). Multimedia application with animated cartoons for teaching science in elementary education. Computers and Education, 52(4),741-748. https://doi. org/10.1016/j.compedu.2008.11.018.

Dale, A., \& Newman, L. (2005). Sustainable development, education and literacy. International Journal of Sustainability in Higher Education, 6(4), 351-362. https://doi. org/10.1108/14676370510623847.

Duran, L.B. \& Duran, E. (2004). The 5E Instructional Model: A Learning Cycle Approach for Inquiry-Based Science Teaching. Science Education Review, 3(2), 49-58.

Ergin, I. (2012). Constructivist approach based 5E model and usability instructional physics. Latin-American Journal of Physics Education, 6(1), 14-20.

Evangelista, E.V., Ayuste, T.O.D., Belmi, R.M., Butron, B.R., Cortez, L.A.S., Evangelista, L.T., \& Tondo, J.E. (2015). Development and Evaluation of Grade 7 and 8 Biokit. The Normal Lights, 8(2), 8-10.

Fazelian, P., Naveh ebrahim, A., \& Soraghi, S. (2010). The effect of $5 \mathrm{E}$ instructional design model on learning and retention of sciences for middle class students. Procedia-Social and Behavioral Sciences, 5, 140-143. https://doi.org/10.1016/j. sbspro.2010.07.062

Felder, R.M., \& Silverman, L.K. (1988). Learning and teaching styles in engineering education. Engineering Education, 78(7), 674-681.

Halpern, D.F. (1998). Teaching critical thinking for transfer across domains: Disposition, skills, structure training, and metacognitive monitoring. American Psychologist, 53(4), 449-455.

Humston, R., \& Ortiz-Barney, E. (2007). Evaluating course impact on student environmental values in undergraduate ecology with a novel survey instrument. Teaching Issues and Experiments in Ecology, 5, 9-12.

Jones, C. (2010). Interdisciplinary approach-advantages, disadvantages, and the future benefits of interdisciplinary studies. Essai, 7(1), 26.

Kals, E., Schumacher, D., \& Montada, L. (1999). Emotional affinity toward nature as a motivational basis to protect nature. Environment and Behavior, 31(2), 178-202. https://doi. org/10.1177/00139169921972056 
Keller, H.W., \& Everhart, S.E. (2010). Importance of myxomycetes in biological research and teaching. Fungi, 3, 13-27.

Keller, H.W., Kilgore, C.M., Everhart, S.E. , Carmack, G.J., Crabtree, C.D., \& Scarborough, A.R. (2008). Myxomycete plasmodia and fruiting bodies: Unusual occurrences and user friendly study techniques. Fungi, 1, 24-37.

Klees, G., \& Piepenbring, M. (2018). Animated life cycles of fungi and plants with spores for teaching. Journal of Biological Education, 52, 130-142. https://doi.org/10.1080/00219266.20 17.1285805

Longshaw, S. (2009). Creativity in science teaching. School Science Review, 90(332), 91-94.

Macabago, S.A.B., \& dela Cruz, T.E.E. (2012). Development of a Myxomycete Photoguide as a Teaching Tool for Microbial Taxonomy. Journal of Microbiology and Biology Education, 13(1), 67. doi: 10.1128/jmbe.v13i1.362.

Mayer, R.E., \& Moreno, R. (2002). Animation as an aid to multimedia learning. Educational Psychology Review, 14(1), 8799. https://doi.org/10.1023/A:1013184611077

Nakagaki, T., Yamada, H., \& Tóth, A. (2000). Intelligence: Maze-solving by an amoeboid organism. Nature, 470, 72-77.

Nakagaki, T. (2001). Smart behavior of a true slime moulds in a labyrinth. Research in Microbiology, 152, 767-770.

Novozhilov, Y.K., Shchepin, O.N., Alexandrova, A.V., Popov, E.S., and Dagamac, N.H.A. (2018). Altitudinal patterns of diversity of myxomycetes (Myxogastria) across tropical forests of Southern Vietnam. Protistology, 12, 81-96.

Ramsden, P., \& Moses, I. (1992). Associations between research and teaching in Australian higher education. Higher Education, 23(3), 273-295.

Reid, C.R., Latty, T., Dussutour, A., \& Beekman, M. (2012). Slime mold uses an externalized spatial "memory" to navigate in complex environments. Proceedings of the National Academy of Sciences, 109(43), 17490-17494. https://doi. org/10.1073/pnas.1215037109

Riener, C., \& Willingham, D. (2010). The myth of learning styles. Change: The magazine of higher learning, 42(5), 3235. https://doi.org/10.1080/00091383.2010.503139.

Rogoff, B. (1994). Developing understanding of the idea of communities of learners. Mind, Culture and Activity, 1(4), 209229. 10.1080/10749039409524673

Samuelsson, I.P., \& Kaga, Y. (2008). The contribution of early childhood education to a sustainable society. Paris: Unesco.

Schnittler, M., Dagamac, N.H.A., \& Novozhilov, Y.K. (2017). Biogeographical patterns in myxomycetes. In S.L. Stephenson \& C. Rojas (eds.), Myxomycetes: Biology, systematics, biogeography and ecology. Academic Press, San Diego. pp. 299331.

Schnittler, M., Novozhilov, Y.K., Romeralo, M. Brown, M., \& Spiegel, F.W. (2012). Myxomycetes and Myxomycete-like organisms. In W. Frey (ed.), Englers syllabus of plant families, Vol. 4. Borntrager, Stuttgart. pp. 12-88.

Stephenson, S.L. (2011). From morphological to molecular: studies of myxomycetes since the publication of the Martin and Alexopoulos (1969) monograph. Fungal Diversity, 50, 2134.

Tuna, A., \& Kacar, A. (2013). The effect of $5 E$ learning cycle model in teaching trigonometry on students' academic achievement and the permanence of their knowledge. International Journal on New Trends in Education and Their Implications,
4(1), 73-87.

Tural, G., Akdeniz, A.R., \& Alev, N. (2010). Effect of 5E teaching model on student teachers' understanding of weightlessness. Journal of Science Education and Technology, 19(5), 470-488. http://dx.doi.org/10.1007/s10956-015-9583-

Uitto, A., Juuti, K., Lavonen, J., \& Meisalo, V. (2006). Students' interest in biology and their out-of-school experiences. Journal of Biological Education, 40(3),124-129. https://doi.or $\mathrm{g} / 10.1080 / 00219266.2006 .9656029$

Vaske, J.J., \& Kobrin, K.C. (2001). Place attachment and environmentally responsible behavior. Journal of Environmental Education, 32(4), 16-21. https://doi. org/10.1080/00958960109598658

Winsett, K. E., dela Cruz, T.E.E., \& de Basanta, D.W. (2017). Myxomycetes in education: The use of these organisms in promoting active and engaged learning. In S.L. Stephenson and C. Rojas (eds.), Myxomycetes: Biology, systematics, biogeography and ecology. Academic Press, San Diego. pp. 389-412. https://doi.org/10.1016/B978-0-12-805089-7.00012-3 